\title{
SND1 wt Allele
}

National Cancer Institute

\section{Source}

National Cancer Institute. SND1 wt Allele. NCI Thesaurus. Code C96332.

Human SND1 wild-type allele is located in the vicinity of $7 q 31.3$ and is approximately 440 $\mathrm{kb}$ in length. This allele, which encodes staphylococcal nuclease domain-containing protein 1 , is involved in the modulation of RNA interference and transcription. 